\title{
Tacit Collusion under Destination- and Origin-Based Commodity Taxation*
}

\author{
Andreas HAUFLER \\ University of Konstanz and Christian-Albrechts-Universität, Kiel \\ Guttorm SCHJELDERUP
}

Norwegian School of Economics and Business Administration and LOS

\begin{abstract}
The paper employs a standard model of dynamic price competition to study how international principles of value-added taxation affect the stability of collusive agreements when producers in an international duopoly agree not to export into each other's home market. If costs of production are zero, international tax differentials reduce support for collusive agreements under the destination, but not under the origin principle. When positive costs of production are introduced, however, the ranking of the two tax principles becomes ambiguous. We also show that tax harmonization - taken to imply an increase in the VAT rate of the low-tax country - increases the likelihood of tacit collusion under both the destination principle and the origin principle.
\end{abstract}

keywords: commodity taxation, dynamic price competition

JEL classification: H7, L1

${ }^{*}$ This paper was written while the second author was visiting the University of Konstanz. We thank seminar participants in Konstanz, Copenhagen and Kiel, in particular Bernd Genser, Morten Hviid, Søren Bo Nielsen, Jürgen Meckl, Raimondos Pascalis-Møller, Christian Seidl, Christian Schulze, Peter Birch Sørensen and Frank Stähler for helpful comments and suggestions. Financial support from the Research Council of Norway, grant no. 124559/510, is greatly appreciated. 


\section{Introduction}

The completion of the European Union's internal market has had the explicit aim of fostering competition and efficiency in the Union. At the same time the abolition of internal border controls has profound implications for indirect taxation by EU member states since the conventional administration of the destination principle with border tax adjustments is no longer possible. In general, these complications for value-added taxation in the European Union were seen as the price that was to be paid for the improved working of goods and services markets. The solution found for value-added taxation in the EU, explicitly labelled as 'temporary' but still in force today, was to shift border tax adjustments from physical frontiers to the firms' books of accounts. While this leaves the destination principle in place for transactions between registered traders, cross-border purchases by final consumers are taxed in the country of origin, effectively turning the current scheme of value added taxation in Europe into a hybrid between destination and origin taxation. To limit the extent of private cross border shopping, this change in the administration of the VAT has been accompanied by Community-wide minimum rates for valueadded taxes, as well as special provisions which subject, among others, private mail order purchases to the tax rate of the destination country. ${ }^{1}$

These policy issues have been discussed in two separate strands of the literature, both assuming almost without exception that product markets are perfectly competitive. The first set of papers, dealing with tax rate harmonization, has shown that the minimum rate strategy pursued in the European Union can be given some welfaretheoretic justification under both cooperative and non-cooperative tax setting. In the absence of strategic behaviour on the part of governments an approximation of tax rates aligns relative prices across countries and thus, depending on the tax principle in operation, either improves exchange or production efficiency (see Keen, 1987, 1989; Frenkel, Razin, Sadka, 1991, Ch. 2). Furthermore, a minimum rate policy is generally considered to be an effective strategy to limit harmful competition

\footnotetext{
${ }^{1}$ Experience has shown, however, that complying with these special provisions is costly for mail order firms. Given the growing importance of this industry in the age of electronic shopping, maintaining these special tax regulations may entail significant macroeconomic costs for Europe as a whole. For the United States, for example, it has been estimated by the Advisory Commission on Intergovernmental Relations (ACIR, 1994) that the share of mail ordering could reach as much as 25 percent of total retail sales in the future.
} 
for cross-border shopping. In general models and when governments are welfaremaximizers, the results are not unambiguous because a tax increase in the low-tax country will have counteracting tax base and terms of trade effects on the high-tax region (Mintz and Tulkens, 1986). ${ }^{2}$ With revenue maximizing governments, however, Kanbur and Keen (1993) obtain the sharp result that a mandated tax increase in the low-tax region benefits both countries and hence constitutes an actual Pareto improvement.

The second strand in the literature has addressed the issue whether an integrated region as the EU should switch to the origin principle for its internal commodity trade. The fundamental attractiveness of this alternative derives from the fact that taxing all transactions under the origin principle may be superior to a hybrid scheme of destination and origin taxation, given that a pure destination principle will no longer be a feasible option for European tax policy (see, e.g. Sinn, 1990). It has been shown in recent years that the conditions for the well-known equivalence result between pure origin and destination principles (see Tinbergen Report, 1953) can be substantially relaxed, and equivalence will also hold under certain types of imperfect competition (Lockwood et. al., 1994a), in the presence of third countries adopting the destination principle for international trade (Lockwood et. al., 1994b; Genser, 1996), and in the presence of capital mobility (Bovenberg, 1994; Genser, Haufler and Sørensen, 1995).

Nevertheless, the fundamental requirement for equivalence between the destination and origin principles is that the commodity tax is levied on all goods at the same rate; if this is not the case, then the switch to the origin principle will have real effects. If markets are perfectly competitive then - by the production efficiency theorem (Diamond and Mirrlees, 1971) - there is a general argument in favour of the destination principle, since it implies that relative price distortions fall on consumer rather than producer prices and thus international trade remains based on the principle of comparative advantage. Hence the case of perfectly competitive product markets offers some support for the decision to maintain the destination principle

\footnotetext{
${ }^{2}$ In a follow-up paper, de Crombrugghe and Tulkens (1990) argue that the tax base effect always dominates and hence the tax increase in the low-tax regions is always beneficial for the high-tax region. This result is derived, however, under the assumption that the objective function of the high-tax region is concave in the low-tax region's tax rate, a condition which cannot generally be expected to hold (see Haufler, 1998).
} 
even in an integrated region. ${ }^{3}$

Recently, however, Keen and Lahiri (1998) have introduced a powerful argument in favour of the origin principle when there is imperfect competition in product markets. They consider coordinated and non-coordinated tax policy under the two tax principles when there is one firm in each of two countries and the cost structures of the firms differ. A core argument for the superiority of the origin principle in this framework is that the origin principle necessarily equates consumer prices across countries and national tax rates can be targeted to correct production distortions. Hence, when tax rates are free to vary internationally, the origin principle is generally able to attain a first-best allocation even for differing cost structures between firms, whereas the same is not true under the destination principle (Keen and Lahiri, 1998, Proposition 2).

Note, however, that in the analysis of Keen and Lahiri (1998) the welfare gains from the switch to the origin principle do not generally derive from a more competitive market structure and the authors do not link the issue of value-added taxation to the European Union's goal of fostering competition between firms in the internal market. This is where the present paper attempts to go one step further by analyzing the interaction between commodity taxation and market structure. The fundamental idea is that the taxation of intra-Community trade and services may in fact be used to support the process of market liberalization and enforce more competitive pricing strategies on the part of firms. More specifically, the focus of our analysis will be on the conditions under which implicit collusion between monopolists in different national markets breaks up, and we compare how likely this is to happen under the destination principle on the one hand and the origin principle on the other. ${ }^{4}$

The approach we take is that of dynamic price competition and tacit collusion, borrowed from the industrial organization literature (see Tirole, 1988, Chapter 6,

\footnotetext{
${ }^{3}$ Note, however, that the production efficiency theorem only ranks the destination and the origin principle in terms of the achievable world welfare under coordinated tax setting. When taxes are set non-cooperatively (and perfect competition prevails in goods markets) neither of the two tax principles Pareto dominates the other (see Lockwood, 1993).

${ }^{4}$ There is empirical evidence for the continued presence of illegal 'secret cartels' in the EU, e.g. in the cement industry (see Lommerud and Sørgard, 1998) and in the car industry. The VW group, for example, was recently fined by the EU Commission for trying to prevent cross border trade of new cars. Researchers estimate that a substantial share of what is frequently labelled as trade costs arise because of international cartels (see Smith and Venables, 1988).
} 
for an introduction). The theory of repeated games has meanwhile been applied to a number of different contexts, including international trade (Pinto, 1986; Rotemberg and Saloner, 1989; Lommerud and Sørgard, 1998) and international monetary economics (Froot and Klemperer, 1989; Meckl, 1996). However, we are not aware that this approach has so far been applied to issues of international taxation.

In our benchmark model the two national product markets are of equal size and costs of production are zero for both firms. The only asymmetry then derives from exogenous differences in VAT rates in the two firms' respective home countries. It turns out in this case, perhaps surprisingly, that tax differentials have a larger effect under the destination principle, and that the stability of the collusive agreement will consequently be lower under destination-based commodity taxation. When positive costs of production and differences in market size are introduced, however, the results become less clear-cut. In addition, our framework allows us to also study the effects of a forced increase in the VAT rate of the low-tax country on the stability of the collusive agreement. Here we obtain the general result - which contrasts with the above-mentioned literature on tax harmonization under perfect competition - that an alignment of tax rates is harmful, in the sense that it stabilizes the (socially undesirable) secret cartel.

To derive these results, we proceed as follows. In section 2 we present the model of dynamic price competition as it applies in our context. Section 3 then discusses the stability of collusive arrangements under the destination and the origin principle in the benchmark model with zero costs of production. We consider both price (Bertrand) and quantity (Cournot) competition when one firm decides to leave the 'cartel' and enters the other market. Section 4 compares the results and summarizes the conclusions from our benchmark model with respect to the choice between the destination and the origin principle and the international harmonization of tax rates. Section 5 analyses the robustness of these results when differences in market size and positive costs of production are incorporated. Section 6 concludes.

\section{The analytical framework}

We consider two firms, labelled by $i \in\{1,2\}$ and located in country 1 and 2, respectively. The two firms produce amounts $x_{i}$ of an identical and homogenous good. Our analysis is partial equilibrium in the sense that we focus on the imperfectly 
competitive market (or the two national markets) for good $x$. Implicitly there is an untaxed, tradeable numeraire good in the background which ensures that a switch from the destination to the origin principle will be non-neutral.

We follow the standard set-up of infinitely repeated games and assume, as is usual in this literature, that the Pareto optimal equilibrium from the viewpoint of the two firms will be realized in equilibrium (see Tirole, 1988, p. 247). In our international framework, tacit collusion between the two firms implies that each firm refrains from exporting and each firm is thus a monopolist in its home market. ${ }^{5}$ However, either firm may find it profitable to defect from this implicit agreement and export to the other market. Since it is assumed that the collusive agreement is illegal, retaliation against the defecting firm must be carried out through actions by the other firm (trigger strategy equilibrium). Hence if firm $i$ at time $t$ deviates from the cartel solution and exports to country $j$, it will first (in period $t$ ) catch firm $j$ by surprise. In the following we will call this the deviation phase of the game. In $t+1$, however, firm $j$ retaliates by exporting to market $i$ and from then on duopoly competition in both markets remains forever. This is the punishment phase of the game. It is a standard result under this set of assumptions that if firm $i$ defects at all, it will do so in the first period $(t=0)$, and export competition will then prevail in $t=1,2, \ldots \infty .^{6}$ Finally, in line with the assumption that governments cannot effectively 'control' the imperfectly competitive market for good $x$ we assume that different producer prices can be set in the two markets under both monopolistic and duopolistic market structures.

We denote by $\pi_{i}^{M}$ the profits of firm $i$ if it acts as a monopolist in its domestic market, $\pi_{i}^{E}$ are the extra profits in period 0 when the firm defects and exports into the other market, and $\pi_{i}^{D}$ are the total duopoly profits (earned in both markets together) of firm $i$ under mutual export competition. Denoting by $\delta_{i}$ the discount

\footnotetext{
${ }^{5}$ There is evidence of this type of collusion among firms. The competitive regulatory agencies in Norway, Sweden and Denmark have taken coordinated action in bringing to court Scandinavian firms in the plastic pipe industry and electronics industry for colluding by creating exclusive national territories (Berlingske Tidende, 7 February, 1999, p. 1 - see also economy section in the same issue).

${ }^{6}$ At first sight it might seem implausible that this punishment strategy is in the interest of firm $j$. Abreu (1986) has shown, however, that the threat to permanently revert to duopoly competition is the optimal (subgame-perfect) strategy of firm $j$.
} 
factor of firm $i$, defection from the cartel solution will be unprofitable when

$$
\frac{\pi_{i}^{M}}{1-\delta_{i}} \geq\left(\pi_{i}^{M}+\pi_{i}^{E}\right)+\left(\frac{\delta_{i}}{1-\delta_{i}}\right) \pi_{i}^{D} \quad \forall i \in\{1,2\},
$$

where we have used the summation rules for infinite series starting at time $t=0$ and $t=1$, respectively. The LHS of this inequality gives the discounted sum of monopoly profits in all periods whereas the RHS gives total profits in the defection period 0 (the sum of domestic monopoly profits and profits in the export market) and duopoly profits in both markets thereafter.

Provided that $\pi_{i}^{M}>\pi_{i}^{D}$ this expression can be rearranged to give the following "stability condition" for the secret cartel: ${ }^{7}$

$$
\theta_{i} \geq \bar{\theta}_{i}^{k, m}=\frac{\pi_{i}^{E}}{\pi_{i}^{M}-\pi_{i}^{D}} \quad \forall i \in\{1,2\}
$$

In eq. (1) $\theta_{i} \equiv \delta_{i} /\left(1-\delta_{i}\right)$ is the relative discount factor of firm $i$ and $\bar{\theta}_{i}^{k, m}$ denotes the critical value of this factor that just leaves the firm indifferent between staying in the secret cartel and defecting. These critical values depend on both the nature of competition (Bertrand or Cournot, $k \in\{B, C\}$ ) and the tax principle in operation (destination or origin principle, $m \in\{D P, O P\}$ ).

Since the gains from defecting accrue in $t=0$, but the losses due to export competition are felt only later, it is intuitive that the cartel will be more stable, the higher are the firms' relative discount factors $\theta_{i}$ (i.e., the closer the absolute discount factor $\delta_{i}$ is to its maximum value of unity). We will assume in the following that the relative discount factor $\theta$ is the same for both firms, an obvious interpretation being that they both calculate their discount factor from the common market interest rate. ${ }^{8}$ The critical values $\bar{\theta}_{i}$ will, however, differ between the two firms when the profit terms in eq. (1) differ because of an underlying asymmetry. The firm with the higher critical value of $\bar{\theta}_{i}$ will then be the one which is more likely to break the collusive arrangement and hence it is this firm's $\bar{\theta}_{i}$ that is binding for the stability of

\footnotetext{
${ }^{7}$ Of course, if $\pi_{i}^{M}<\pi_{i}^{D}$ then it will always be profitable for firm $i$ to leave the collusive agreement, since it will gain not only in the deviation phase but also in the 'punishment' phase. Since we focus only on conditions under which tax policy affects the stability of collusive arrangements, these cases will be disregarded in our analysis.

${ }^{8}$ In general the discount factor may vary from period to period, but we ignore this possibility in the following. See Martin (1993, ch. 5) for a discussion of the additional effects raised by timevariant discount factors.
} 
the secret cartel. ${ }^{9}$ In the following analysis we thus focus on the comparison of the binding critical values of $\bar{\theta}_{i}$ under different tax principles and different behavioural assumptions concerning duopoly competition. The implication is that the higher is $\bar{\theta}_{i}$ under a given scenario, the lower is the likelihood that the collusive agreement will be stable, in the sense that only a smaller range of relative discount factors $\theta$ sustains the cartel solution.

We assume that each country levies an ad valorem tax $t_{i}$ on good $x$. The focus on ad valorem taxes is motivated by the fact that we are concerned with valueadded taxation, but it will also have some convenient analytical implications. The ad valorem tax rates $t_{i}$ remain exogenous throughout our analysis and, importantly, generally differ between countries. Throughout the paper, and without loss of generality, we adopt the convention that country 1 is the high tax country and $t_{1} \geq t_{2}$.

In our benchmark scenario we make two simplifying assumptions. First the costs of production are assumed to be zero for both firms (a frequent assumption in the literature on dynamic price competition). Second, demand functions in both markets are linear and markets are assumed to be of equal size. Both of these assumptions will be relaxed in section 5 .

\section{The benchmark model with zero costs}

Before we turn to the separate analyses of the destination and the origin principle, we can compute each firm's monopoly profits $\pi_{i}^{M}$. These are unaffected by the international tax principle in operation because with two monopolies each serving the domestic market only, there is no trade in good $x$ between the two countries. Denoting consumer and producer prices by $q_{i}$ and $p_{i}$ respectively, demand in each market is given by

$$
x_{i}=a-q_{i}=a-\left(1+t_{i}\right) p_{i} \quad \forall i \in\{1,2\} .
$$

The monopoly problem can be solved by choosing either the producer price $p_{i}$ or the quantity sold $x_{i}$. In both cases it is straightforward to show that the solution to

\footnotetext{
${ }^{9}$ If firm $j$ has the higher critical value of $\bar{\theta}$, say, firm $i$ could improve the stability of the cartel by offering firm $j$ a new contract (for example a fifty-fifty split of the two markets). Such market sharing, however, poses a problem since it is difficult to detect breach of the agreement. The cost of monitoring, therefore, provides cartels with an incentive to set up exclusive territories, thereby making it easier to detect defection (see Marvel 1982, and Tirole 1988, pp. 183 and 185).
} 
the maximization problem yields

$$
p_{i}=\frac{a}{2\left(1+t_{i}\right)}, \quad q_{i}=\frac{a}{2}, \quad x_{i}=\frac{a}{2} \quad \forall i \in\{1,2\}
$$

implying monopoly profits of

$$
\pi_{i}^{M}=\frac{a^{2}}{4\left(1+t_{i}\right)} \quad \forall i \in\{1,2\} .
$$

Note from (3) that the burden of the commodity tax is fully shifted backwards into producer prices. This incidence result is a consequence of our combined assumptions that the commodity tax is ad valorem rather than specific, and that costs of production are zero. ${ }^{10}$ Furthermore, note from (4) that given the assumption of identical market size ( $a$ is the same in both markets), monopoly profits vary in the two markets to the extent that tax rates differ. These model implications will turn out to be important for our results.

In the following we derive explicit expressions for the remaining profit terms in eq. (1), i.e., exporting profits $\pi_{i}^{E}$ and duopoly profits $\pi_{i}^{D}$. These terms depend on both the tax principle in operation and the nature of duopoly competition.

\subsection{The destination principle}

Under the destination principle commodity taxes are levied in the country where the good is consumed. This implies that firms located in countries with different commodity tax rates will nevertheless compete in each market on an equal tax footing. We first compute exporting and duopoly profits when price is the strategic variable (Bertrand competition), and then turn to the case of quantity (Cournot) competition.

\subsubsection{Bertrand competition}

If firm $i$ deviates from the cartel solution and exports to market $j(j \neq i)$, firm $j$ is initially unaware of the breach of agreement. Firm $j$ will therefore continue to

\footnotetext{
${ }^{10}$ In contrast to the competitive case, specific and ad valorem taxation are not equivalent with imperfect competition. Venables (1986) and, in more detail, Delipalla and Keen (1992) show that ad valorem taxes lead to lower consumer prices and profits in the oligopoly equilibrium than specific taxes. We will obtain similar results when we introduce positive costs of production in section 5 .
} 
set its monopoly price of $a /\left[2\left(1+t_{j}\right)\right]$. This implies that firm $i$ can - under price competition - capture the whole market in country $j$ by slightly undercutting the price of firm $j$. Under the destination principle, if firm $i$ breaks out of the cartel and exports to market $j$, its exports are taxed at the rate $t_{j}$. Firm $i$ 's profits in market $j$ will then be (marginally below) the monopoly profits that can be earned in market $j$

$$
\pi_{i}^{E(B, D P)}=\frac{a^{2}}{4\left(1+t_{j}\right)} \quad \forall i, j \in\{1,2\}, i \neq j .
$$

When firm $j$ observes that firm $i$ has defected from the cartel, it will respond by exporting to market $i$ and there will then be export competition in both markets. Since costs are zero and the destination principle implies the same burden of taxation for both firms in each market, price competition means that, in equilibrium, both firms set producer prices equal to zero. Thus, profits in the price duopoly are

$$
\pi_{i}^{D(B, D P)}=0 \quad \forall i \in\{1,2\} .
$$

We can now substitute (4), (5) and (6) into (1). It follows that it is unprofitable for firm $i$ to defect from the cartel iff

$$
\theta \geq \bar{\theta}_{i}^{B, D P}=\frac{1+t_{i}}{1+t_{j}} \quad \forall i, j \in\{1,2\}, i \neq j .
$$

Given our convention that country 1 is the high tax country, it is immediately seen from (7) that the critical value of firm $1, \bar{\theta}_{1}^{B, D P}$, is the higher one. ${ }^{11}$ Intuitively it is the firm in the high-tax country 1 which has the greater incentive to defect from the cartel because its gains from defecting are given by the (one-period) monopoly profits in the relatively profitable (low-tax) market 2 while the losses occur in the less profitable home market 1 . Due to our assumption that $\theta$ is the same for both firms, $\bar{\theta}_{1}^{B, D P}$ will thus be the binding constraint that limits the range of discount factors supporting the secret cartel under the destination principle and Bertrand competition. For later purposes of comparison, we can therefore restrict our attention to this single critical value of firm 1 .

\subsubsection{Cournot competition}

When quantity is the strategic variable and firm $i$ defects from the collusive arrangement, then it will be impossible for firm $i$ to capture the entire export market $j$. In

\footnotetext{
${ }^{11}$ Note that for equal tax rates $\left(t_{1}=t_{2}\right)$, eq. (7) reduces to $\bar{\theta}=1$; from the definition $\theta \equiv \delta /(1-\delta)$ this implies a critical discount rate of $\delta=1 / 2$. This reproduces a standard result in symmetric models of repeated price competition (see Tirole, 1988, p. 246).
} 
the case of two suppliers to one market we have to extend the aggregate demand function (2) to get

$$
x_{j}^{i}+x_{j}^{j}=a-q_{j} \quad \forall i, j \in\{1,2\}, i \neq j,
$$

where the superscript denotes the supply of firms $i, j$ and the subscript refers to market $j$. It is easily checked that firm $i$ 's profit maximum must generally lie on the reaction curve

$$
x_{j}^{i}=\frac{a-x_{j}^{j}}{2} \quad \forall i, j \in\{1,2\}, i \neq j .
$$

In period 0 firm $j$ will now fix its monopoly quantity of $x_{j}^{j}=a / 2$ [see eq. (3)]. Firm $i$ takes this quantity as given and chooses the profit-maximizing supply in its export market from (9). This yields $x_{j}^{i}=a / 4$, giving exporting profits of

$$
\pi_{i}^{E(C, D P)}=\frac{a^{2}}{16\left(1+t_{j}\right)} \quad \forall i, j \in\{1,2\}, i \neq j .
$$

Comparing (10) with eq. (5), it is obvious that the maximum profits that can be earned in the deviation phase are reduced under the assumption of quantity competition. However, profits in the duopoly equilibrium also depend on the nature of competition. From the two reaction functions given in (9), the symmetric Cournot equilibrium quantity chosen by each firm in each market is $a / 3$. Hence total duopoly profits for firm $i$, aggregated over both markets, are

$$
\pi_{i}^{D(C, D P)}=\frac{a^{2}}{9}\left(\frac{1}{1+t_{i}}+\frac{1}{1+t_{j}}\right) \quad \forall i, j \in\{1,2\}, i \neq j .
$$

Using (4), (10) and (11) in (1), firm $i$ has an incentive to support the collusive agreement if

$$
\theta \geq \bar{\theta}_{i}^{C, D P}=\frac{9\left(1+t_{i}\right)}{4\left[5\left(1+t_{j}\right)-4\left(1+t_{i}\right)\right]} \quad \forall i, j \in\{1,2\}, i \neq j .
$$

Again it is immediately seen from (12) that it is the firm in the high-tax country 1 which has the higher critical value of $\bar{\theta}$, and is thus more likely to defect from the secret cartel. The intuition is the same as in the case of Bertrand competition. Under the destination principle, the relative competitiveness of the two firms is unaffected by commodity tax differentials. Any tax asymmetry $\left(t_{i} \neq t_{j}\right)$, however, will affect the relative attractiveness of the two national markets and the firm in the high-tax country will gain more, and lose less, from defecting as compared to the firm located in the low-tax region. 


\subsection{The origin principle}

Under the origin principle, commodities are taxed in the country of production, but are exempted from tax in the importing country. Hence tax differentials now affect the relative competitiveness of the two firms in each market.

\subsubsection{Bertrand competition}

If firm $i$ defects from the cartel and exports to market $j$ it can again capture the entire market by slightly undercutting firm $j$. The difference to the previous section is that firm $i$ will now base its pricing decision on the monopoly consumer price charged by firm $j$ which, from equation (3), is equal to $a / 2$. Given that the tax rate applicable to firm $i$ 's sales to market $j$ is $t_{i}$, the maximum producer price that firm $i$ can charge is $a /\left[2\left(1+t_{i}\right)\right]$. Given the consumer price of $a / 2$, the demand in market $j$ is also $a / 2$, implying maximum profits from exporting equal to

$$
\pi_{i}^{E(B, O P)}=\frac{a^{2}}{4\left(1+t_{i}\right)} \quad \forall i \in\{1,2\} .
$$

In contrast to eq. (5) it is now the tax rate in the defecting firm's home country, rather than the tax rate in the foreign market, which determines the profitability of exporting. In the duopoly equilibrium, the low-tax firm also has a tax advantage under the origin principle, as long as producer prices are positive. This tax advantage disappears, however, when producer prices are zero and ad valorem taxes are levied. Since zero is the Bertrand equilibrium price in the absence of production costs, tax differentials are again immaterial in the duopoly equilibrium and profits for each firm are

$$
\pi_{i}^{D(B, O P)}=0 \quad \forall i \in\{1,2\}
$$

Substituting (4), (13) and (14) into (1), firm $i$ will not breach the collusive agreement if

$$
\theta \geq \bar{\theta}_{i}^{B, O P}=1
$$

Thus under the origin principle and Bertrand competition the critical value of $\bar{\theta}$ is identical for the two firms, implying that both firms have the same incentive to defect from the secret cartel. While it seems counterintuitive that tax differentials do not matter under the origin principle and price competition, the result is easily explained. 
The firm located in the low-tax country has the higher gains from exporting to the other market [eq. (13)], but its costs from defecting are also higher, since a higher level of monopoly profits is given up [eq. (4)]. These effects just offset each other, making tax differentials irrelevant for the decision to leave the collusive agreement.

\subsubsection{Cournot competition}

If firm $i$ defects under Cournot competition, it will set its export supply $x_{j}^{i}$ knowing that firm $j$ sells $x_{j}^{j}=a / 2$. From (9) the optimal level of $x_{j}^{i}$ is $a / 4$, as under the destination principle. The consumer price in market $j$ is then $a / 4$. However the producer price at which goods can be sold in the export market will now depend on the tax rate of the defecting firm's home country, and is equal to $a /\left[4\left(1+t_{i}\right)\right]$. This gives profits in the deviation phase equal to

$$
\pi_{i}^{E(C, O P)}=\frac{a^{2}}{16\left(1+t_{i}\right)} \quad \forall i \in\{1,2\} .
$$

In the non-cooperative phase both firms will again set output levels at $a / 3$, implying a consumer price in each market of $a / 3$. Firm $i$ thus earns profits of $a^{2} /\left[9\left(1+t_{i}\right)\right]$ in each market so that total duopoly profits are

$$
\pi_{i}^{D(C, O P)}=\frac{2 a^{2}}{9\left(1+t_{i}\right)} \quad \forall i \in\{1,2\} .
$$

In the same way as before, we substitute (16), (17) and (4) into (1) to derive the condition under which firm $i$ upholds the collusive agreement. This is

$$
\theta_{i} \geq \bar{\theta}_{i}^{C, O P}=\frac{9}{4}
$$

Hence the critical value of $\bar{\theta}$ is again identical for the two firms, for the same reasons as under price competition. Tax differentials influence profits in each stage of the game, but since all terms in (1) depend only on the domestic tax rate, their effects cancel for the decision of whether to stay in the secret cartel or break out.

\section{Comparison of results}

It is now time to summarize and compare the results of our analysis in the previous sections. Table 1 collects the critical levels of $\bar{\theta}_{i}^{k, m}$ under the destination and the 
Table 1: Critical values of $\bar{\theta}_{i}^{k, m}$ with zero costs of production

\begin{tabular}{|c|c|c|}
\hline $\bar{\theta}_{i}^{k, m}$ & Destination Principle & Origin Principle \\
\hline \multirow{3}{*}{ Bertrand } & $\frac{1+t_{1}}{1+t_{2}}$ & 1 \\
\hline Cournot & $\frac{9\left(1+t_{1}\right)}{4\left[5\left(1+t_{2}\right)-4\left(1+t_{1}\right)\right]}$ & $\frac{9}{4}$ \\
\hline
\end{tabular}

origin principle and for both Bertrand and Cournot competition [eqs. (7), (12), (15) and (18)]. As previously stated, it is the firm in the high-tax country (country 1, by convention) that is more likely to leave the collusive agreement under the destination principle, whereas the critical values under the origin principle apply to both firms simultaneously.

The first observation from Table 1 concerns the comparison of Bertrand vs. Cournot competition. It is immediately seen that a collusive agreement is less likely in our setting under quantity (Cournot) competition than under price (Bertrand) competition; this is true under both destination and origin based commodity taxation. Put differently, the range of discount factors that sustains a secret cartel is wider under Bertrand competition. This result obtains even though the extra profits that can be reaped in the deviation phase from penetrating the other market are generally higher under Bertrand competition (because the defecting firm can capture the entire foreign market). However, in our benchmark scenario, price competition implies that profits in the duopoly equilibrium fall to zero under either the destination or the origin principle. It is this severe effect of competition in the later stages of the game which dominates in equilibrium and "disciplines" the parties, making collusion more likely under price competition. ${ }^{12}$

\footnotetext{
${ }^{12}$ This intuition is, of course, closely related to Abreu's (1986) result that a maximum punishment strategy is optimal for firm $j$ if it wants to deter firm $i$ from breaking the collusive agreement (see footnote 6 ). For an early statement of the result that duopoly competition is more fierce under Bertrand than under Cournot competition, see Vives (1985).
} 


\subsection{Choice of international tax principle}

Turning to the implications of our benchmark model for tax policy, we first compare the stability of tacit collusion between firms under destination versus origin based commodity taxation. This is given in the following proposition.

Proposition 1: When tax rates differ across countries and costs of production are zero, a collusive agreement is less likely under the destination principle than under the origin principle, irrespective of the nature of duopoly competition.

At first sight, this is a surprising and counterintuitive result. One would expect that it is the origin principle which gives the firm in the low-tax country a competitive advantage and makes it more likely for this firm to break out from a collusive agreement. As our detailed analysis in the previous section has shown, however, this reasoning is true only for the deviation phase. In the punishment phase the losses for the firm in the low-tax country are also higher, because they accrue in its relatively more profitable home market. These effects just compensate each other under the origin principle. In contrast, under the destination principle the effects of tax differentials on the gains and losses from defection are mutually reinforcing rather than offsetting. Here, the firm in the high-tax country has more to gain from defecting because it enters the relatively more profitable low- tax market abroad, but the losses in the punishment phase accrue in the relatively less profitable home market. This interpretation highlights the role that international tax differentials play in "destabilizing" the collusive arrangement under the destination principle. It is immediately seen from Table 1 that for harmonized tax rates the critical $\bar{\theta}$ 's are the same under the destination and the origin principle, no matter whether quantity or price competition occurs.

Turning to the normative implications of Proposition 1, it is obvious that a stable secret cartel is undesirable from a social welfare perspective since it restricts output more, and causes a higher deadweight loss, than if the two firms are engaged in duopoly competition. The difference is particularly visible under Bertrand competition where prices in the duopoly equilibrium are equal to marginal costs and hence are set at their welfare maximizing levels. With Cournot competition, aggregate output in the duopoly equilibrium falls short of the socially optimal level, but it is still unambiguously higher than if both firms act as monopolists in their respective 
home markets. Hence, as a partial equilibrium result, Proposition 1 implies that the destination principle is to be preferred over the origin principle, in the sense that it implies a wider range of discount factors under which duopoly competition will result.

This implication contrasts with the result by Keen and Lahiri (1998) that the origin principle is the preferred choice in a setting where the market structure is exogenously given by duopoly competition, and firms face different cost structures. In this framework, national tax rates can be directly targeted at production distortions under the origin, but not under the destination principle. Hence, when tax rates are free to vary internationally, the origin principle - but not the destination principle - is generally able to attain a first-best allocation (Keen and Lahiri, 1998, Proposition 2). The argument made above in favour of the destination principle in a tacit collusion setting is rather different in nature, focusing on induced changes in market structure rather than on production efficiency. Nevertheless our Proposition 1 shows that the existence of imperfect competition does not necessarily reverse the case that can be made for the destination principle under perfect competition in product markets. ${ }^{13}$

Finally, Proposition 1 emphasizes that our ranking of the destination and the origin principle does not depend on the nature of competition. This is not a standard result in related analyses that compare the effects of different policy measures under price and quantity competition of firms. Schjelderup and Sørgard (1997), for example, show that a decentralized multinational sets a transfer price above or below marginal costs, depending on whether strategic interaction with other firms in the market occurs through prices or quantities. Similarly, Lommerud and Sørgard (1998) - in a model of trade liberalization and collusion - find that collusion becomes easier to sustain under Bertrand competition after a reduction in trade costs, while the opposite is true under Cournot competition.

Of course, the assumption that markets are of equal size has so far ensured that profitability in the two different markets depends only on international differences in

\footnotetext{
${ }^{13}$ Of course, the results that the destination principle supports a Pareto superior allocation in a purely competitive economy and in an isolated sector characterized by tacit collusion do not jointly imply that it necessarily dominates the origin principle in a general equilibrium setting where different distortions interact. However, this caveat applies equally to the argument in favour of the origin principle made by Keen and Lahiri (1998).
} 
Table 2: Effects of an increase in $t_{2}$ on critical values of $\bar{\theta}_{i}^{k, m}$

\begin{tabular}{|l|c|c|}
\hline $\bar{\theta}_{i}^{k, m}$ & Destination Principle & Origin Principle \\
\hline Bertrand & $\bar{\theta}_{1} \downarrow$ & $\bar{\theta}=$ const. \\
\hline Cournot & $\bar{\theta}_{1} \downarrow$ & $\bar{\theta}=$ const. \\
\hline
\end{tabular}

tax rates. Furthermore, the result that the low-tax firm cannot utilize its tax advantage in the Bertrand duopoly equilibrium under the origin principle, and therefore makes zero profits in the punishment phase, is due to our assumption that costs of production are zero. In section 5 we will thus test the robustness of our results when differences in market size and positive costs of production are incorporated into the analysis.

\subsection{Tax harmonization}

There are different definitions of tax harmonization. Tax harmonization could, for example imply that both countries agree to change their VAT rates to some higher or lower level of taxation, or that they both adjust their tax rates towards a common average. In the following we interpret tax harmonization as a process where the lowtax country unilaterally increases its VAT rate and thus narrows the tax differential to the high-tax country. This has, for example, been the approach to commodity tax harmonization within the European Union, and it is also a common definition in the literature (e.g. Kanbur and Keen, 1993).

Hence we consider in the following the effects of a rise in the tax rate of country 2 (the low-tax country by our convention) on the critical values of $\bar{\theta}_{i}^{k, m}$, as given in Table 1. The results are shown in Table 2 and are summarized in the following proposition:

Proposition 2: When costs of production are zero, a tax increase in the low-tax country makes a collusive arrangement more likely under the destination principle, but has no effects under the origin principle.

Proposition 2 is easily understood from our earlier discussion. We have emphasized that tax differentials are critical in 'destabilizing' the collusive arrangement 
under the destination principle since they increase the incentive for the firm in the high-tax country 1 to enter the foreign market 2. A tax rise in market 2 reduces the profitability of exporting into this market and hence lowers the incentive for firm 1 to defect from the secret cartel. Under the origin principle, instead, tax differentials have no net effect on the decision to leave the cartel so that tax rate changes in either country can clearly have no effect.

The results summarized in Proposition 2 provide an interesting contrast to the beneficial effects of tax rate harmonization that have been found in the previous literature assuming perfect competition in product markets. At a very basic level, tax harmonization aligns either relative consumer prices (under the destination principle) or relative producer prices (under the origin principle), thus improving either international exchange or production efficiency (see, e.g., Frenkel, Razin and Sadka, 1991, ch. 2). For the case of the destination principle, Keen $(1987,1989)$ has furthermore shown that this fundamental argument for an international alignment of tax rates carries over to a second-best setting with many taxes. With imperfect competition Keen et al. (1998) show, however, that tax harmonization is harmful under the origin principle, even when it is beneficial under the destination principle. ${ }^{14}$ Our setting yields different results in that the negative effects of tax rate harmonization arise primarily under the destination principle. (But - to anticipate a result from section 5-tax rate harmonization also stabilizes collusive agreements under the origin principle when costs of production are positive.) Nevertheless, we also find that imperfect competition can turn around the conventional arguments for tax rate harmonization in perfectly competitive economies.

\section{Extensions}

In this section we will discuss two extensions to our previous analysis. We first incorporate differences in market size between the two countries and then turn to the case where the two firms face positive, but symmetric, costs of production.

\footnotetext{
${ }^{14}$ A similar result is also implicit in Keen and Lahiri (1998) where tax differentials are needed under the origin principle to correct differential distortions in product markets caused by diverging marginal costs.
} 


\subsection{Differences in market size}

To capture differences in the size of the markets 1 and 2, we generalize aggregate demand functions to incorporate a size parameter $s_{i}{ }^{15}$

$$
x_{i}=s_{i}\left(a-q_{i}\right)=s_{i}\left[a-\left(1+t_{i}\right) p_{i}\right] \quad \forall i \in\{1,2\} .
$$

With this demand function, the optimal producer price for a monopolist remains unchanged at $a /\left[\left(2\left(1+t_{i}\right)\right]\right.$ [cf. eq. (3)], but the level of sales at this price is now $x_{i}=s_{i} a / 2$. Hence monopoly profits are also proportional to $s_{i}$ and are given by

$$
\pi_{i}^{M}=\frac{s_{i} a^{2}}{4\left(1+t_{i}\right)} \quad \forall i \in\{1,2\}
$$

We confine our analysis of this extension to the case of price competition; the case of quantity competition offers few additional insights. Also, we can now treat the destination and the origin principle simultaneously since the differences discussed in sections 2 and 3 remain intact in the extended model considered here. Under both tax principles firm $i$ 's profits in the deviation phase from exporting to country $j$ depend on the size of market $j$ :

$$
\begin{array}{ll}
\pi_{i}^{E(B, D P)}=\frac{s_{j} a^{2}}{4\left(1+t_{j}\right)} & \forall i, j \in\{1,2\}, i \neq j, \\
\pi_{i}^{E(B, O P)}=\frac{s_{j} a^{2}}{4\left(1+t_{i}\right)} & \forall i, j \in\{1,2\}, i \neq j .
\end{array}
$$

Furthermore, under both tax principles, Bertrand duopoly profits are again zero for both firms since costs are still assumed to be zero

$$
\pi_{i}^{D(B, D P)}=\pi_{i}^{D(B, O P)}=0 \quad \forall i \in\{1,2\} .
$$

For the destination principle, we substitute (19), (20) and (22) into (1), whereas for the origin principle we insert (19), (21) and (22) into (1). This gives the following critical levels of $\bar{\theta}$ under each of the two tax principles:

$$
\begin{gathered}
\bar{\theta}_{i}^{B, D P}=\frac{s_{j}}{s_{i}} \frac{\left(1+t_{i}\right)}{\left(1+t_{j}\right)} \quad \forall i, j \in\{1,2\}, i \neq j, \\
\bar{\theta}_{i}^{B, O P}=\frac{s_{j}}{s_{i}} \quad \forall i, j \in\{1,2\}, i \neq j .
\end{gathered}
$$

${ }^{15}$ This demand function can be seen as the aggregation over different numbers of identical individuals in the two countries; see, e.g., Haufler and Wooton (1999). 
Under the origin principle we see immediately from (24) that the firm located in the smaller country will have the higher level of $\bar{\theta}$. This result is, of course, fully in line with our earlier argument that it will be the firm in the less profitable market which is more likely to defect from the collusive agreement. In the case of the destination principle, eq. (23) shows that the effects of differences in tax rates and in market size are both relevant and they can, in principle, be mutually reinforcing or mutually offsetting. If the small country is also the high-tax country 1 , then it will certainly be the firm in country 1 which is more likely to defect from the collusive arrangement. Furthermore, in this case the destination principle will continue to imply the higher critical value of $\bar{\theta}$ and hence make the sustainability of a secret cartel less likely. In contrast, if the small country has the lower tax rate $t_{2}$, then it it unclear under the destination principle which firm is more likely to defect. Also, in this case the results of our benchmark scenario are turned around and it will now be the origin principle which implies the higher critical value of $\bar{\theta}$.

The question is then whether there is a systematic relationship between differences in market size on the one hand, and differences in commodity tax rates on the other. The analysis of commodity tax competition for cross-border shopping by Kanbur and Keen (1993) suggests that small countries will systematically choose lower tax rates than their larger neighbours. The intuition for this result - which is derived under the assumption that there are no other taxes - is that the small country faces a more elastic domestic commodity tax base and hence gains more, and loses less, from setting a low tax rate than the larger country. However, a look at current value-added tax rates in the European Union does not support this result since many of the smaller EU countries - in particular, but not only in Scandinavia - have some of the highest VAT rates in Europe. Furthermore, these countries have even increased their value-added tax rates in the internal market, in order to finance a reduction in direct taxes. These tax reforms, in particular the switch to dual income tax systems with substantially reduced rates of capital taxation, indicate that it is primarily the capital tax base which is very elastic for small countries. Hence small countries will, above all, set lower capital tax rates than their larger neighbours whereas tax base losses through cross-border shopping seem to be limited in the European Union. ${ }^{16}$

\footnotetext{
${ }^{16}$ See, for example, Gordon and Nielsen (1997) for an empirical study of Denmark which suggests that the avoidance of income taxes is a far more serious problem for this country than cross-border
} 
From these observations an argument can be made that, for a given level of overall spending, small countries will rely less on relatively mobile capital income taxes and more on the relatively immobile value-added tax base. This argument about the structure of tax systems in large vs. small countries thus points in precisely the opposite direction as the analysis in Kanbur and Keen, which considers only commodity taxes. In this case our benchmark result for the stability of secret cartels under the destination vs. the origin principle would be upheld - and even reinforced - in the presence of differences in market size.

\subsection{Positive costs of production}

Another relevant extension is to incorporate positive costs of production. This extension has many similarities with the analysis of specific taxes (cf. footnote 10) and thus can also be thought of as relaxing the assumption that taxes in our model are levied ad valorem. We confine the analysis to the symmetric case where both firms incur the same constant marginal cost $c$ per unit produced. Profits then change to

$$
\pi_{i}=p_{i} x_{i}-c x_{i}=\left(p_{i}-c\right)\left[a-p_{i}\left(1+t_{i}\right)\right] \quad \forall i \in\{1,2\}
$$

With this profit function, it is straightforward to show that optimal prices and quantities for a monopolist are

$$
p_{i}=\frac{1}{2}\left[\frac{a}{\left(1+t_{i}\right)}+c\right], \quad q_{i}=\frac{1}{2}\left[a+c\left(1+t_{i}\right)\right], \quad x_{i}=\frac{a-c\left(1+t_{i}\right)}{2} .
$$

Notice that with positive costs the burden of the commodity tax changes; some part of it is now shifted forward into consumer prices [compare $q_{i}$ in eqs. (26) and (3)]. Thus, the quantity sold by the monopolist now depends negatively on the domestic tax rate. The prices and quantities given by (26) yield monopoly profits of

$$
\pi_{i}^{M}=\frac{\left[a-\left(1+t_{i}\right) c\right]^{2}}{4\left(1+t_{i}\right)} \equiv \frac{\alpha_{i}^{2}}{4\left(1+t_{i}\right)} \forall i \in\{1,2\}
$$

For each firm, exporting profits $\pi_{i}^{E}$ and duopoly profits $\pi_{i}^{D}$ can now be derived under the different scenarios, in the same way as we have done in section 3 . This task is relegated to the appendix. It is also shown there that firm 1 continues to have the higher critical value of $\bar{\theta}$ under the destination principle, for either Bertrand or shopping, despite a $10 \%$ VAT differential to neighbouring Germany. 
Table 3: Critical values of $\bar{\theta}_{i}^{k, m}$ with positive costs

\begin{tabular}{|c|c|c|}
\hline $\bar{\theta}_{i}^{k, m}$ & Destination Principle $\left(\bar{\theta}_{1}\right)$ & Origin Principle $\left(\bar{\theta}_{2}\right)$ \\
\hline \multirow{3}{*}{ Bertrand } & $\frac{\left(1+t_{1}\right)}{\left(1+t_{2}\right)} \frac{\alpha_{2}^{2}}{\alpha_{1}^{2}}$ & $\frac{\left[\alpha_{2}+c\left(t_{1}-t_{2}\right)\right] \alpha_{1}}{\alpha_{2}^{2}-8 c\left(t_{1}-t_{2}\right) \alpha_{1}}$ \\
\hline Cournot & $\frac{9\left(1+t_{1}\right) \alpha_{2}^{2}}{4\left[5\left(1+t_{2}\right) \alpha_{1}^{2}-4\left(1+t_{1}\right) \alpha_{2}^{2}\right]}$ & $\frac{9\left[\alpha_{2}+c\left(t_{1}-t_{2}\right)\right]^{2}}{4\left(9 \alpha_{2}^{2}-8\left[\alpha_{2}+c\left(t_{1}-t_{2}\right)\right]^{2}\right)}$ \\
\hline
\end{tabular}

where $\alpha_{i}=\left[a-\left(1+t_{i}\right) c\right]$ and $\alpha_{1}<\alpha_{2}$

Cournot competition of firms. Under the origin principle, however, the critical levels of $\bar{\theta}$ differ now for the two firms, and firm 2 will be more likely to leave the collusive agreement (again, this is true for both Bertrand and Cournot competition). The results from the appendix are summarized in Table 3.

It emerges from this analysis that positive, but symmetric costs of production, make the comparison of cartel stability under the destination vs. the origin principle ambiguous. Proposition 1 must thus be modified in the presence of positive costs of production. On the other hand, tax differentials now 'destabilize' the collusive agreement under both the destination and the origin principle so that Proposition 2 in the benchmark scenario can be strengthened. Our findings are summarized in the following proposition, and discussed in turn.

Proposition 3: (a) As costs of production increase, relative to market size, a stable collusive agreement becomes less likely under the origin principle than under the destination principle.

(b) With positive costs of production, tax harmonization makes a collusive agreement more likely under both the destination and the origin principle, and for either Bertrand or Cournot competition.

To interpret part (a) of Proposition 3, it is best to focus on the case of Bertrand competition. The expressions for $\bar{\theta}_{i}^{k, m}$ in Table 3 are less complex here, but the 
intuition gained carries over to the case of Cournot competition as well. ${ }^{17}$

Under the destination principle, we see that the difference in the tax factors is now weighed with the difference in the quantities that a monopolist can sell in each market [note from eq. (26) that $\alpha_{i}=2 x_{i}$ ]. Since $\alpha_{2}>\alpha_{1}$ for $t_{1}>t_{2}$ the critical value of $\bar{\theta}_{1}$ must unambiguously rise, relative to our benchmark case (Table 1 ). Intuitively, with positive costs of production, the ad valorem tax rate of country $i$ has a negative effect on sales in this country and this negative effect is stronger in the high-tax country 1 . Hence positive costs of production increase the profitability differential in the two markets, raising the incentive for firm 1 to defect from the secret cartel.

Under the origin principle, the weights introduced by the different $\alpha_{i}$ also change the critical values $\bar{\theta}_{2}$ at which firm 2 leaves the cartel. Here this isolated effect works in the direction of lowering $\bar{\theta}_{2}$, since exporting gains accrue in the high-tax country whereas monopoly profits are lost in the more profitable (low-tax) home country. However, positive costs of production also introduce a second effect under the origin principle, given by the terms $c\left(t_{1}-t_{2}\right)$. It is seen from Table 3 that these terms unambiguously increase $\bar{\theta}_{2}$ by raising the numerator and reducing the denominator of the fraction. Intuitively, the tax advantage that the firm in the low-tax country 2 has over its competitor in country 1 will now also extend to the gross-of-tax cost component that is shifted forward into consumer prices [eq. (26)]. Other things equal, this increases the gains for firm 2 in the deviation phase (given in the numerator) and it also ensures that profits in the punishment phase will not fall to zero (the extra term in the denominator). The latter result stems from the fact that the Bertrand equilibrium is now asymmetric. For the firm in the high-tax country 1 to make zero profits its producer price must equal unit $\operatorname{costs} c$. The higher ad valorem tax on this price implies, however, that firm 2 can now charge a producer price above $c$ and still (marginally) underbid the consumer price of firm 1.

It follows from this discussion that the comparison between the critical values

\footnotetext{
${ }^{17}$ Simple checks for the consistency of our results can be performed by setting $c=0$ (in which case the results in Table 3 collapse to those of Table 1), and by setting $t_{1}=t_{2}$ (implying that $\bar{\theta}$ reduces to 1 under Bertrand competition, and to $9 / 4$ when competition is Cournot). Note further that the range of parameter values for which the denominator becomes negative (indicating that total duopoly profits for the defecting firm exceed its monopoly profits in the home market) is enlarged by the assumption of positive costs. As in the benchmark scenario, we will ignore these cases in which the secret cartel cannot be stable (cf. footnote 7 ) .
} 
Table 4: Numerical comparison of $\bar{\theta}$ for different parameter values

$$
t_{1}=0.3, t_{2}=0.2
$$

\begin{tabular}{|l|c|c|c|c|}
\hline & $\bar{\theta}_{1}^{B, D P}$ & $\bar{\theta}_{2}^{B, O P}$ & $\bar{\theta}_{1}^{C, D P}$ & $\bar{\theta}_{2}^{C, O P}$ \\
\hline (i) $a=3, c=0.1$ & 1.09 & 1.03 & 3.86 & 2.40 \\
(ii) $a=3, c=0.3$ & 1.11 & 1.10 & 4.40 & 2.82 \\
(iii) $a=3, c=0.5$ & 1.13 & 1.20 & 5.29 & 3.54 \\
(iv) $a=3, c=1.0$ & 1.22 & 1.72 & 19.26 & 29.01 \\
(v) $a=10, c=1.0$ & 1.11 & 1.10 & 4.40 & 2.82 \\
\hline
\end{tabular}

of $\bar{\theta}_{i}^{k, m}$ under the destination vs. the origin principle will now depend on the quantitative magnitudes of two counteracting effects: a large market size parameter $a$ will tend to increase the incentive for the high-tax firm 1 to defect from the secret cartel, and thus lead to a higher critical value of $\bar{\theta}$ under the destination principle. In contrast, if the cost component $c$ gets large, this increases the incentive for the low-tax firm 2 to leave the collusive agreement, and thus tends to imply a higher value of $\bar{\theta}$ under the origin principle.

Table 4 presents the results from some numerical experiments for exogenously chosen tax rates $t_{1}=0.3$ and $t_{2}=0.2$. $^{18}$ For sufficiently low values of $c$ the results from our benchmark analysis continue to hold [cases (i) and (ii)]. When $c$ is successively increased, however, the ranking of the two tax principles is reversed and the origin principle yields the higher value of $\bar{\theta}$. This switch generally occurs first under Bertrand competition and then, for sufficiently high levels of $c$, also under Cournot competition. Finally, note from the comparison of cases (iii) and (v) that multiplying both $a$ and $c$ with the same factor leaves all absolute entries unchanged. Hence it is the relative importance of the cost parameter, in comparison to market size, which determines the results.

Turning now to Proposition 3 (b) on the effects of tax rate harmonization, the appendix confirms that $\partial \bar{\theta}_{i}^{k, m} / \partial t_{2}<0$ holds for any of the four entries in Table 3 . Under the destination principle, the intuition for the result that tax harmonization

\footnotetext{
${ }^{18}$ It should be noted that changing either the level of tax rates or the tax differential has significant effects on the absolute value of each $\bar{\theta}_{i}$, but does not critically affect the difference between these terms, in which we are interested.
} 
reduces the critical level of $\bar{\theta}_{1}$ is unchanged from our discussion in section 4 . The new result is that an increase in the low-tax country's tax rate now also increases the likelihood of tacit collusion under the origin principle. This result is easily understood from our above discussion of the terms $c\left(t_{1}-t_{2}\right)$, which give the tax advantage of the firm in the low-tax country 2. Since, under the origin principle, this tax advantage is critical in determining that firm 2 is more likely to defect from the collusive agreement if costs of production are positive, an increase in $t_{2}$ must reduce the incentive for this firm to leave the secret cartel.

\section{Conclusions}

In this paper we have analyzed the effects of alternative commodity tax regimes on the stability of collusive agreements between firms. Such non-competitive behaviour, aimed at maintaining national monopolies, is still present in certain segments of the European industry and the question we have raised here is whether tax policy can help to promote the incentives for firms to leave the collusive arrangement and enter foreign markets. We have asked two distinct questions for tax policy. First, is the destination or the origin principle to be preferred as a means of inducing competitive behaviour between firms? Second, how is the incentive to leave a secret cartel affected by tax rate harmonization, as currently discussed in the European Union?

The results of our simple model show that the answer to the first of these questions is not clear cut. While first intuition may suggest that the origin principle is more likely to induce firms in low-tax countries to enter foreign markets, our analysis has shown that tax differentials also play an important role under the destination principle, since they make it attractive for firms in high-tax markets to enter relatively more profitable low-tax markets abroad. When markets are of equal size and costs of production are zero (our benchmark scenario), the likelihood for a secret cartel to break up is indeed higher if the destination principle is in place. However, in a more general framework with positive costs of production and differences in market size, the ranking of the two tax principles depends on the precise combination of costs of production on the one hand and market size parameters on the other. In any case, however, the result of Keen and Lahiri (1998) that the origin principle dominates the destination principle in an international duopoly with firms differing in cost structures does not generally carry over to the different setting analyzed here. 
From this one may draw the cautious conclusion that models of imperfect competition may yield different policy implications depending on underlying assumptions of market structure and the institutional set up between firms.

Turning to the second policy question, our analysis has lead to the unambiguous result that tax harmonization stabilizes socially undesirable secret cartels. This is true under both the destination principle and - in the case of positive costs of production - the origin principle and is intuitively explained by the 'destabilizing' effect that tax differentials have for collusive agreements under both tax principles considered. This result reinforces earlier arguments against tax rate harmonization derived from a political economy perspective (Brennan and Buchanan, 1980; Siebert and Koop, 1993), a link that should not be too surprising since imperfect competition in product markets and imperfect competition in 'political markets' can be seen as two alternative departures from the conventional model underlying most analyses of international taxation. If both of these 'market failures' are seen as relevant, then they indeed raise serious doubts about the medium-term plans of the European Commission to fully harmonize VAT rates in the European Union (see European Communities-Commission, 1996).

It needs to be stressed, however, that our analysis can at best be seen as a first step in exploring the effects of alternative tax policies on the dynamics of firm interaction in imperfectly competitive markets. Of all the simplifying features, the most important is perhaps the assumption that tax rates are exogenous in our model. Endogenizing tax rates would allow to analyze the strategic interaction between governments and firms and thus link our framework more closely to the existing literature on tax competition. This is an extension that we hope to do in future work. 


\section{Appendix}

\section{Derivation of Table 3}

We derive the critical levels of $\bar{\theta}_{i}^{k, m}$ in the case of positive costs of production, as summarized in Table 3.

For the destination principle and Bertrand competition, the extra profits for firm $i$ from exporting are, using $\alpha_{j}=a-c\left(1+t_{j}\right)$

$$
\pi_{i}^{E(B, D P)}=\frac{\alpha_{j}^{2}}{4\left(1+t_{j}\right)} .
$$

Profits in the duopoly equilibrium are $\pi_{i}^{D(B, D P)}=0$ for both firms, since differences in tax rates do not affect the symmetric cost structure of the two firms under the destination principle. Together with (27) in the main text this gives

$$
\bar{\theta}_{i}^{B, D P}=\frac{\left(1+t_{i}\right)}{\left(1+t_{j}\right)} \frac{\alpha_{j}^{2}}{\alpha_{i}^{2}} .
$$

With Cournot competition, following the same procedure as in section 3 the extra profits in the deviation phase are for firm $i$ :

$$
\pi_{i}^{E(C, D P)}=\frac{\alpha_{j}^{2}}{16\left(1+t_{j}\right)},
$$

whereas total profits in the duopoly equilibrium can be computed as

$$
\pi_{i}^{D(C, D P)}=\frac{\alpha_{i}^{2}}{9\left(1+t_{i}\right)}+\frac{\alpha_{j}^{2}}{9\left(1+t_{j}\right)} .
$$

Combining (27) in the main text with (A.3) and (A.4) gives

$$
\bar{\theta}_{i}^{C, D P}=\frac{9\left(1+t_{i}\right) \alpha_{j}^{2}}{4\left[5\left(1+t_{j}\right) \alpha_{i}^{2}-4\left(1+t_{i}\right) \alpha_{j}^{2}\right]} .
$$

Since by assumption $t_{1}>t_{2}$, it is immediately seen from (A.2) and (A.5) that firm 1 has the greater incentive to defect from the cartel under both destination and origin based taxation $\left[\bar{\theta}_{1}^{k, D P}>\bar{\theta}_{2}^{k, D P} \forall k \in\{B, C\}\right]$.

Under the origin principle and Bertrand competition, the exporting profits for firm $i$ are

$$
\pi_{i}^{E(B, O P)}=\frac{\left[\alpha_{i}+c\left(t_{j}-t_{i}\right)\right] \alpha_{j}}{4\left(1+t_{i}\right)} .
$$


Profits in the duopoly equilibrium are not identical now for firms 1 and 2. Profits will be zero for the high-tax firm 1 , but this leaves a positive profit margin for firm 2 . We get

$$
\pi_{1}^{D(B, O P)}=0, \quad \pi_{2}^{D(B, O P)}=\frac{2 c\left(t_{1}-t_{2}\right) \alpha_{1}}{\left(1+t_{2}\right)} .
$$

Using (A.6), (A.7) and (27) in the main text gives critical values of $\bar{\theta}$ that differ for the two firms

$$
\begin{aligned}
& \bar{\theta}_{1}^{B, O P}=\frac{\left[\alpha_{1}-c\left(t_{1}-t_{2}\right)\right] \alpha_{2}}{\alpha_{1}^{2}} \\
& \bar{\theta}_{2}^{B, O P}=\frac{\left[\alpha_{2}+c\left(t_{1}-t_{2}\right)\right] \alpha_{1}}{\alpha_{2}^{2}-8 c\left(t_{1}-t_{2}\right) \alpha_{1}} .
\end{aligned}
$$

Finally, under the origin principle and Cournot competition exporting profits are

$$
\pi_{i}^{E(C, O P)}=\frac{\left[\alpha_{i}+c\left(t_{j}-t_{i}\right)\right]^{2}}{16\left(1+t_{i}\right)}
$$

whereas profits in the duopoly equilibrium are

$$
\pi_{i}^{D(C, O P)}=\frac{2\left[\alpha_{i}+c\left(t_{j}-t_{i}\right)\right]^{2}}{9\left(1+t_{i}\right)} .
$$

From (A.9), (A.10) and (27) we get

$$
\bar{\theta}_{i}^{C, O P}=\frac{9\left[\alpha_{i}+c\left(t_{j}-t_{i}\right)\right]^{2}}{4\left\{9 \alpha_{i}^{2}-8\left[\alpha_{i}+c\left(t_{j}-t_{i}\right)\right]^{2}\right\}} .
$$

To show that the low-tax firm 2 will have the higher level of $\bar{\theta}$ under the origin principle, we first consider the case of Bertrand competition. Comparing the numerators of the two expressions in (A.8) gives

$$
\begin{aligned}
& \operatorname{NUM}\left(\bar{\theta}_{2}^{B, O P}\right)-N U M\left(\bar{\theta}_{1}^{B, O P}\right)=2 a c\left(t_{1}-t_{2}\right)+c^{2}\left[\left(1+t_{2}\right)^{2}-\left(1+t_{1}\right)^{2}\right] \\
= & 2 c\left(t_{1}-t_{2}\right)(a-c)-c^{2}\left(t_{1}-t_{2}\right)\left(t_{1}+t_{2}\right)=2 c\left(t_{1}-t_{2}\right)\left[a-c\left(1+\frac{t_{1}+t_{2}}{2}\right)\right]>0
\end{aligned}
$$

since $t_{1}>t_{2}$ by assumption and the square bracket must be positive for positive sales in both countries [cf. eq. (26)]. Similarly, comparing the denominators in (A.8) gives, after obvious manipulations:

$$
\operatorname{DEN}\left(\bar{\theta}_{2}^{B, O P}\right)-D E N\left(\bar{\theta}_{1}^{B, O P}\right)=-c\left(t_{1}-t_{2}\right)\left[6 \alpha_{1}-c\left(t_{1}-t_{2}\right)\right]<0 .
$$

This must be negative since $\alpha_{1}<c\left(t_{1}-t_{2}\right)$ would lead to a negative numerator for $\bar{\theta}_{1}^{B, O P}$ in (A.8), implying that firm 1 makes negative profits from exporting to country 2 . Hence it must be true that $\bar{\theta}_{2}^{B, O P}>\bar{\theta}_{1}^{B, O P}$ since it has the larger numerator, but the smaller denominator. 
Similarly, we can compare the two expressions implied by (A.11). Here it is completely straightforward to show that $\bar{\theta}_{2}^{C, O P}$ implies the larger numerator but the smaller denominator in comparison to $\bar{\theta}_{1}^{B, O P}$, and hence the fraction must unambiguously be larger.

With the results that firm 1 has the higher level of $\bar{\theta}_{i}$ under the destination principle, but firm 2 is more likely to defect from the collusive agreement under the origin principle, equations (A.2), (A.5), (A.8) and (A.11) give the results summarized in Table 3.

\section{Derivation of Proposition 3(b)}

We differentiate the four terms $\bar{\theta}_{i}^{k, m}$ in Table 3 with respect to $t_{2}$, using our definition of $\alpha_{i} \equiv\left[a-\left(1+t_{i}\right) c\right]$, which implies $\partial \alpha_{2} / \partial t_{2}=-c$. Under the destination principle there are no ambiguities because the numerator of both $\bar{\theta}_{1}^{B, D P}$ and $\bar{\theta}_{1}^{C, D P}$ is falling in $t_{2}$, while the denominator is rising. The analysis for the origin principle and Cournot competition is also straightforward since the numerator is unambiguously falling in $t_{2}$ and the counteracting terms in the denominator can be cancelled to show that the denominator is increasing in $t_{2}$. Finally, under the origin principle and Bertrand competition, we get

$$
\frac{\partial \bar{\theta}_{2}^{B, O P}}{\partial t_{2}}=\frac{-2 c \alpha_{1} D E N-2 c\left(4 \alpha_{1}-\alpha_{2}\right) N U M}{(D E N)^{2}}<0 .
$$

This must be negative since $D E N$ and $N U M$ are positive profit terms and $\left(4 \alpha_{1}-\alpha_{2}\right)$ must also be positive. The latter follows from $\alpha_{1}-\alpha_{2}=-c\left(t_{1}-t_{2}\right)$ and $\alpha_{1}>c\left(t_{1}-t_{2}\right)$ from our above argument that firm 1 cannot make negative profits from exporting to country 2. Hence, we have $\partial \bar{\theta}_{i}^{k, m} / \partial t_{2}<0 \forall k \in\{B, C\}, m \in\{D P, O P\}$. 


\section{References}

Abreu, D., 1986, Extremal equilibria of oligopoly supergames, Journal of Economic Theory 39, 191-225

ACIR (Advisory Commission on Intergovernmental Relations), 1994, Taxation of interstate mail order sales. 1994 revenue estimates (Washington, D.C.)

Bovenberg, A.L., 1994, Destination- and origin-based taxation under international capital mobility, International Tax and Public Finance 1, 247-273

Brennan, G. and J. Buchanan, 1980, The power to tax. Analytical foundations of a fiscal constitution (Cambridge University Press)

de Crombrugghe, A. and H. Tulkens, 1990, On Pareto improving tax changes under fiscal competition, Journal of Public Economics 41, 335-350

Delipalla, S. and M. Keen, 1992, The comparison between ad valorem and specific taxation under imperfect competition, Journal of Public Economics 49, 351367

European Communities-Commission, 1996, A common system of value added taxation. A programme for the Internal Market, Document COM (96) 328 (Brussels)

Frenkel, J., A. Razin and E. Sadka, 1991, International taxation in an integrated world (MIT Press, Cambridge, Mass.)

Froot, K. and P.D. Klemperer, 1989, Exchange rate pass-through when market share matters, American Economic Review 79, 637-654

Genser, B., 1996, A generalized equivalence property of mixed international VAT regimes, Scandinavian Journal of Economics 98, 253-262

Genser, B., A. Haufler and P. B. Sørensen, 1995, Indirect taxation in an integrated Europe: Is there a way of avoiding trade distortions without sacrificing national tax autonomy?, Journal of Economic Integration 10, 178-205

Gordon, R.H. and S.B. Nielsen, 1997, Tax avoidance and value-added vs. income taxation in an open economy, Journal of Public Economics 66, 173-197 
Haufler, A., 1998, Asymmetric commodity tax competition - comment on de Crombrugghe and Tulkens, Journal of Public Economics 67, 135-144

Haufler, A. and I. Wooton, 1999, Country size and tax competition for foreign direct investment, Journal of Public Economics 71, 121-139

Kanbur, R. and M. Keen, 1993, Jeux sans frontières: Tax competition and tax coordination when countries differ in size, American Economic Review 83, 877-892

Keen, M., 1987, Welfare effects of commodity tax harmonization, Journal of Public Economics 33, 107-114

Keen, M., 1989, Pareto-improving indirect tax harmonization, European Economic Review 33, 1-12

Keen, M. and S. Lahiri, 1998, The comparison between destination and origin principles under imperfect competition, Journal of International Economics 45, 323-350

Keen, M., S. Lahiri, and P. Raimondos-Møller, 1998, When is policy harmonization desirable?, EPRU working paper 1998/2 (Copenhagen Business School)

Lockwood, B., 1993, Commodity tax competition under destination and origin principles, Journal of Public Economics 53, 141-162

Lockwood, B., D. de Meza and G. Myles, 1994a, When are origin and destination regimes equivalent?, International Tax and Public Finance 1, 5-24

Lockwood, B., D. de Meza and G. Myles, 1994b, The equivalence between destination and non-reciprocal restricted origin tax regimes, Scandinavian Journal of Economics 96, 311-328

Lommerud, K.E. and L. Sørgard, 1998, Trade liberalization and cartel stability, Discussion Paper 1/98 (Norwegian School of Economics and Business Administration, Bergen)

Martin, S., 1993, Advanced Industrial Organization (Blackwell, Mass.)

Marvel, H., 1982, Exclusive dealing, Journal of Law and Economics 25, 1-26 
Mintz, J. and H. Tulkens, 1986, Commodity tax competition between member states of a federation: Equilibrium and efficiency, Journal of Public Economics 29, 133-172

Meckl, J., 1996, Market power of firms and exchange rate fluctuations, Journal of Economics 63, 57-77

Pinto, B., 1986, Repeated games and the reciprocal dumping model of trade, Journal of International Economics 20, 357-366

Rotemberg, J. and G. Saloner, 1989, Tariffs vs. quotas with implicit collusion, Canadian Journal of Economics 22, 237-244

Schjelderup, G. and L. Sørgard, 1997, Transfer pricing as a strategic device for decentralized multinationals, International Tax and Public Finance 4, 277-290

Siebert, H. and M.J. Koop, 1993, Institutional competition versus centralization: Quo vadis Europe?, Oxford Review of Economic Policy 9, 15-30

Sinn, H.-W., 1990, Tax harmonization and tax competition in Europe, European Economic Review 34, 489-504

Smith, A. and A.J. Venables, 1988, Completing the internal market in the European Community: Some industry simulations, European Economic Review 32, 15011525

Tirole, J., 1988, The theory of industrial organisation (MIT Press, Cambridge, Mass.)

Tinbergen Report, 1953, Report on the problems raised by value added taxation in the common market (European Coal and Steel Community - High Authority)

Venables, A.J., 1986, Producton subsidies, import tariffs and imperfectly competitive trade, in D. Greenaway and P.K.M. Tharakan (eds.), Imperfect competition and international trade (Sussex, Wheatsheaf)

Vives, X., 1985, On the efficiency of Cournot and Bertrand competition with product differentiation, Journal of Economic Theory 36, 166-175. 